University of Nebraska - Lincoln

DigitalCommons@University of Nebraska - Lincoln

Faculty Publications: Department of Entomology

1972

\title{
Field Tests of Insecticides against Plagiotrochus cornigerus
}

E. E. Burgess

University of Tennessee, Knoxville

H. E. Williams

University of Tennessee, Knoxville

R. E. Wilkinson

University of Tennessee, Knoxville

E. A. Heinrichs

University of Tennessee, Knoxville, eheinrichs2@unl.edu

Follow this and additional works at: https://digitalcommons.unl.edu/entomologyfacpub

Part of the Entomology Commons

Burgess, E. E.; Williams, H. E.; Wilkinson, R. E.; and Heinrichs, E. A., "Field Tests of Insecticides against Plagiotrochus cornigerus" (1972). Faculty Publications: Department of Entomology. 831.

https://digitalcommons.unl.edu/entomologyfacpub/831

This Article is brought to you for free and open access by the Entomology, Department of at DigitalCommons@University of Nebraska - Lincoln. It has been accepted for inclusion in Faculty Publications: Department of Entomology by an authorized administrator of DigitalCommons@University of Nebraska - Lincoln. 
Published in Journal of Economic Entomology 65:5 (1972), pp. 1484-1485; doi: 10.1093/jee/65.5.1484 Copyright $\odot 1972$ Entomological Society of America. Published by Oxford University Press. Used by permission.

Submitted December 1, 1971.

\title{
Field Tests of Insecticides against Plagiotrochus cornigerus*
}

\author{
E. E. Burgess, ${ }^{1}$ H. E. Williams,${ }^{1}$ R. E, Wilkinson, ${ }^{2}$ and E. A. Heinrichs ${ }^{1}$ \\ 1. Department of Agricultural Biology, University of Tennessee, Knoxville, Tennessee, USA \\ 2. Agricultural Extension Service, University of Tennessee, Knoxville, Tennessee, USA
}

Pin oaks, Quercus palustris Muenchhausen, are one of the important shade trees in west Tennessee. The horned oak-gall wasp, Plagiotrochus cornigerus Osten Sacken, causes a deformation of the twigs and leaves of the tree. The twig gall is a knotty oval enlargement varying in size with hornlike projections which are tubular extensions from the cells of the gall makers (Fig. 1). The alternate generation develops in inconspicuous ovoid blister galls (Fig. 2) along the midrib of major veins of leaves (Felt 1940). According to Craighead (1950), in species of gallflies having alternation of generations, one generation consists only of agamic females, whereas the other consists of both males and females. The former, unisexual, overwinters; the latter, bisexual, reproduces sexually and is the summer stage.

In 1965, K. E. Stewart, an entomologist at the University of Toronto, Ontario, Canada, injected pin oaks with systemic insecticides to evaluate their effectiveness in controlling the leaf gall and the stem gall caused by the horned oak-gall wasp (unpublished information). He found oxydemeton-methyl EC at a rate of $25 \mathrm{~g} \mathrm{AI} / \mathrm{in}$. diameter and technical demeton at a rate of $3 \mathrm{~g} \mathrm{AI} / \mathrm{in}$. diameter were the best materials tested, each resulting in $83 \%$ control. In the present study we attempted to evaluate effectiveness of several systemic insecticides by applying them at the base of the tree.

* Hymenoptera: Cynipidae 


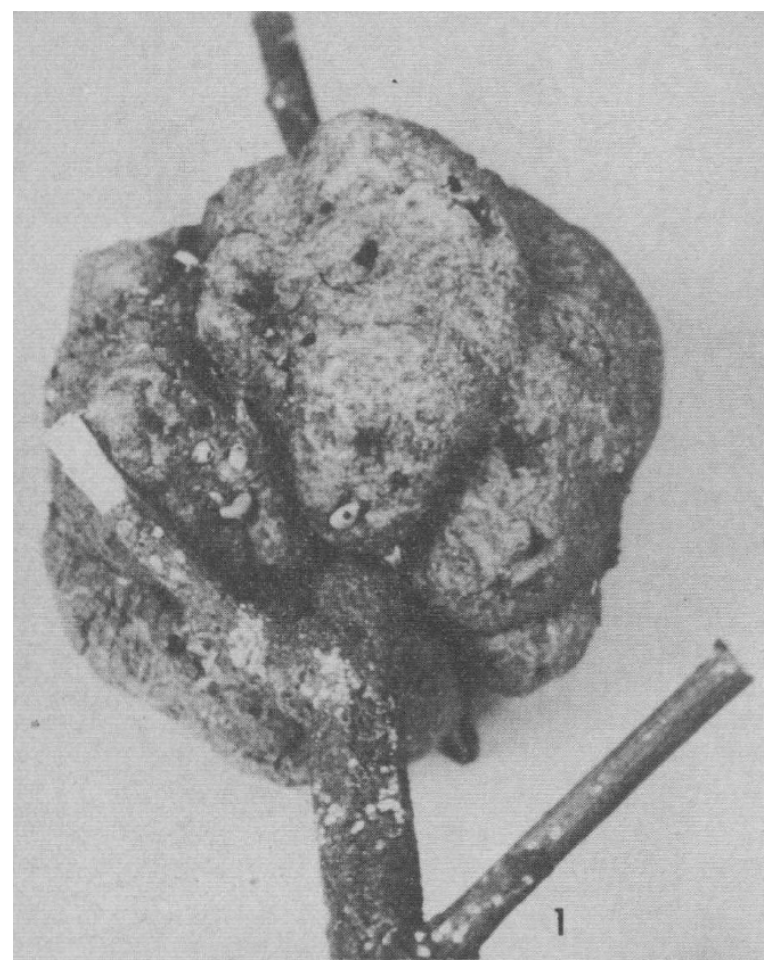

Figure 1. The twig gall of the horned oak-gall wasp on a pin oak.

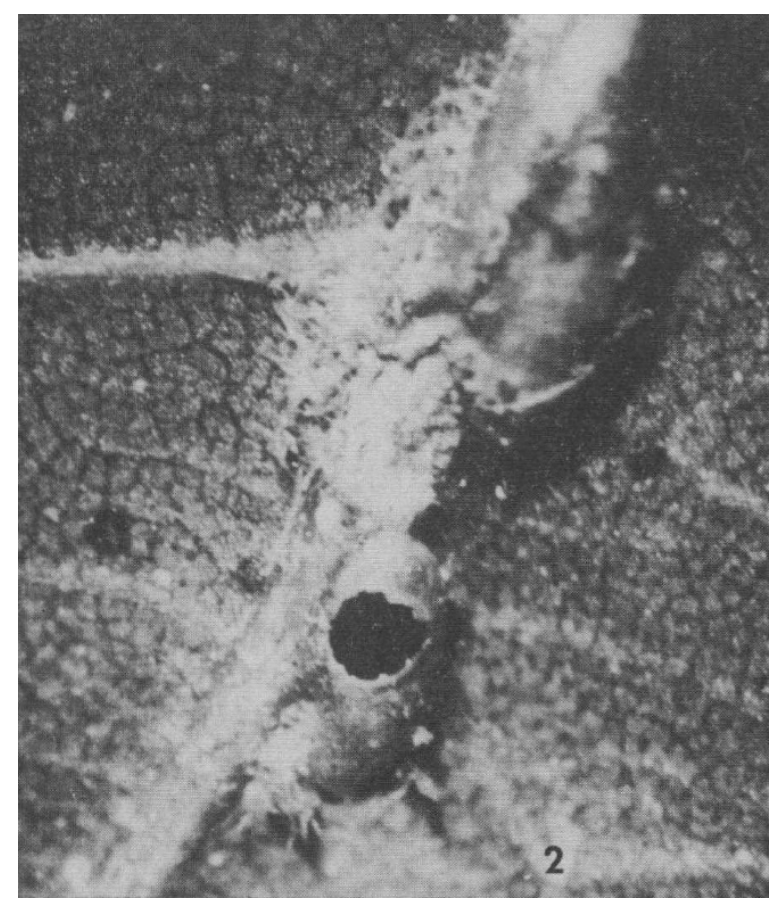

Figure 2. The leaf gall of the horned oak-gall wasp on a pin oak leaf. 


\section{Materials and Methods}

Twig galls were severed from the trees periodically in late february and March. These galls were dissected to see if adults had begun emerging. When a large amount of emergence occurred the chemicals were applied. A test was initiated March 30, 1971, on a group of pin oaks in Memphis, Tennessee. When the eggs from the agamic females were deposited on leaves, chemicals were applied to evaluate their effectiveness in controlling the leaf gall and subsequently the twig gall generation.

Seven insecticides were tested and applied at $0.4 \mathrm{oz} \mathrm{AI} / \mathrm{in}$. DBH. Trees were randomly selected with 4 replications of 8 different treatments. Insecticide granules were applied with a Universal spreader. The emulsifiable concentrates were applied with a hose proportion-sprayer using 15 gal of water/treatment. These materials were distributed on the soil surface in a circular band in the drip line area of the trees.

Dissections of leaf galls were made weekly to examine the condition of the larvae and pupae and to check for adult emergence.

Approximately 2 months following heavy emergence 100 leaves with galls were picked from each replication and counts of emergence holes were taken to evaluate effectiveness of the insecticides.

The data for insecticide effectiveness were analyzed statistically by the analysis of variance, using the " $\mathrm{F}$ " test. The significance of mean comparisons was based on Duncan's multiple range test at the $5 \%$ level.

\section{Results and Discussion}

During the 1st and 2nd weeks of March, a large percentage of empty cells occurred in dissected overwintering twig galls because of adult emergence. This was about 1 month earlier than K. E. Stewart (personal communication) observed in Canada. From 25 dissected leaves May 10, all immatures were in the pupal stage. The bisexual generation was then observed for emergence. At least 10\% emergence from the leaf galls had started by May 26 , and $50-75 \%$ emergence had occurred by May 28 . The bisexual generation was approximately 1 month ahead of Stewart's observations.

Table 1 shows that carbofuran was significantly different from all other treatments with an average of only $6 \%$ emerging from 4 replications. This percentage of emergence indicates a highly satisfactory degree of control. The other treatments did not result in so effective a control. However, dimethoate FC and phorate 10G were also significantly different from the check with a mean emergence of 51 and $52 \%$, respectively. The other 4 treatments were not significantly different from the check. 
Table 1. Relative effectiveness of systemic insecticides for control of the horned oak galls

\begin{tabular}{lcc}
\hline Insecticide & Rate oz. AI/in. diam & \% emerged \\
\hline Carbofuran 10G & 0.4 & $6 \mathrm{a}$ \\
Dimethoate 267F,C & .4 & $51 \mathrm{~b}$ \\
Phorate 10G & .4 & $52 \mathrm{~b}$ \\
Demeton 25E & .4 & $57 \mathrm{bc}$ \\
Disulfoton 15G & .4 & $64 \mathrm{bc}$ \\
Oxydemetom-methyl EC & .4 & $67 \mathrm{bcd}$ \\
Check & & $73 \mathrm{~cd}$ \\
Disulfoton 2G & .4 & $86 \mathrm{~d}$ \\
\hline
\end{tabular}

a. Numbers followed by the same letter are not significantly different at the $5 \%$ level using Duncan's multiple range test.

\section{Conclusion}

Carbofuran was far superior to the other materials tested at equivalent rates for the control of the horned oak-gall wasp. This material will be excellent for commercial use. Dimethoate and phorate showed some promise for homeowners use, but further testing is needed. Of the test insecticides, disulfoton $2 \mathrm{G}$ offered the least plant protection.

\section{References Cited}

Craighead, F. C. 1950. Insect Enemies of Eastern Forests. USDA Miscellaneous Publication 657. 679 p. Felt, E. P. 1940. Plant Galls and Gall Makers. Comstock Publishing Co., New York. 364 p. 